UDC $378.147: 811$

\title{
CHALLENGES AND SOLUTIONS TO DEVELOPING PHONOLOGICAL COMPETENCE OF TECHNICAL STUDENTS IN ESP TEACHING
}

\author{
Nazarenko O.I. \\ National Technical University of Ukraine \\ "Igor Sikorsky Kyiv Polytechnic Institute"
}

DOI: https://doi.org/10.32839/2304-5809/2018-12-64-28

The article is focused on the importance of developing phonological competence as one of the integral component of foreign language communicative competence. It describes the challenges in teaching pronunciation to technical learners. Analysis of students' needs is offered as an effective tool to explore communicative language competences to be developed in ESP to meet the employment market demand for IT and telecoms specialists. The most expedient techniques are described to motivate students to become confident and effective communicators in their academic and job-related environment.

Keywords: ESP, needs analysis, foreign language communicative competence, phonological competence.

Tntroduction. Employment market demand for

Lhighly competent, self-motivated employees with strong people-oriented and relationship-building skills makes lecturers who teach English for Specific Purposes (ESP) find effective methods and techniques to meet students' needs to fit the requirements.

Therefore, a very special attention is to be devoted to needs analysis as it is stated by a number of ESP developers. In this regard, ESP is distinguished from General English by "not the existence of a need as such but rather an awareness of the need" that will have an influence on the language course content and potential to be exploited" [14, p. 53]. Language is learnt to achieve greater linguistic efficiency in academic, professional or work-related environments [1, p. 17-18]. Needs assessment as a teaching tool can help students become more aware, find purpose and interest in their learning, foster positive attitudes and feelings, achieve confidence as a user of the language as well as a learner [13, p. 14-17].

Statement of the problem. As mentioned above, there is a great market demand for employees with skills focused on interaction with people, and at present it might concern to a larger extent such branches as electronic and computer engineering. So, it is obvious that developing communicative competence is becoming crucial in ESP learning. Since communicative language competence comprises linguistic competence, it is important to pay attention to developing phonological knowledge and skills (phonological competence) as one of its integral components [7, p. 13].

Unfortunately, in ESP for technical students pronunciation is one of the most neglected aspects of language teaching. The reason is not that it is ignored, the problem is the lack of time allotted for learning English. To decide whether phonetic accuracy and fluency are early or longer term learning objectives in ESP and what techniques are more efficient and even appealing to meet learners' needs, we should take into account that our students learn the language in non-English environment where there are few opportunities to communicate, moreover, the problem of interference of the native language is evident.

The purpose of the paper to explore the challenges in teaching pronunciation to technical stu- dents in the context of researches provided by leading scientists, to define the most effective techniques to be employed to developing students' phonological competence in ESP to meet the employment market demand for IT (information technology) and telecoms specialists.

Analysis of recent research and publications. English phonetics is considered to be a complex subject. It includes many components that startle a learner at first and the learner does not know what first steps to take in order to obtain skills of an effective communicator or at least be properly understood by a native speaker. According to L. Yates and B. Zielinski "it does not matter how good a learner's vocabulary or grammar is if no one can understand them when they speak! And to be understood, a learner needs a practical mastery of the sounds, rhythms and cadences of English and how they fit together in connected speech" [19, p. 11].

In view of the foregoing, there is no need to emphasize the importance of "clear pronunciation" and its role in spoken communication.

A number of Ukrainian researchers made a considerable contribution into pronunciation teaching: solving the problem of defining phonological competence (S.Y. Nikolaeva, N.F. Borysko); providing innovative processes in English phonetics learning at higher educational institutions (M.V. Broda); analyzing phonetic difficulties of students of non-linguistic specialties (O. Tsvietaieva, O. Znanetska). A lot of foreign scientists and researchers dedicated their works to teaching English pronunciation: (G. Kelly, L. Yates, B. Zielinski, P. Carley, I.M. Mees, B. Collins, H. Fraser, A. Baker, J. Murphy, J. Kenworthy, J. Morley, S. Dabic, etc.).

To present pronunciation in general it consists of two systems: the phonemic system (the sounds: consonants and vowels) and the intonation system (stress and rhythm). L. Yates regards pronunciation as "the production of sounds that we use to make meaning" and the system which includes "the particular sounds of a language (segments), aspects of speech beyond the level of the individual sound, such as intonation, phrasing, stress, timing, rhythm (suprasegmental aspects), how the voice is projected (voice quality) and, in its broadest definition, attention to gestures and expressions that are closely related to the way we speak a language" [18, p. 11]. 
J.P. Geyser presents phonological system dividing it into the following areas: sounds, stress (word, sentence) and intonation. He highlights that "a learner's pronunciation should be intelligible and unambiguous, good enough to satisfy his / her goals" [11, p. 124].

G. Kelly offers to study pronunciation presenting it in two fields: 1) phonetics (the study of speech sounds); 2) phonology (deals with the system and pattern which exist within a particular language $[15$, p. 9]. He regrets that the key problem is that pronunciation teaching is either neglected in classes or tends to be reactive to a problem that arises in the class, and insists on its planning [15, p. 13].

$H$. Fraser proves that pronunciation is an essential ingredient of oral communication. It includes segmental articulation, rhythm, intonation and phrasing, and even peripheral aspects as gestures, body language and eye contact [10, p. 6].

With respect to the fact that pronunciation teaching in ESP is regarded as developing phonological competence, it is presented as a knowledge of, and skill in the perception and production of phonemes each of which has different variants of pronunciation (allophones) and their realization in particular contexts; distinctive features (voicing, rounding, nasality, plosion); syllable structure, the sequence of phonemes, word stress, word tones); sentence phonetics (prosody); sentence stress, rhythm and intonation; phonetic reduction; vowel reduction; strong and weak forms; assimilation; elision [7, p. 116-117].

Since today there is no business which operates without using information and communications technologies, high-performing specialists who provide these technologies are badly demanded in the employment market. The needs analysis [16] showed that a well-developed foreign language communicative competence is crucial for our students in terms of necessity to work with clients from different countries, deal with telecommunications vendors to obtain pricing and technical specifications for available hardware, software or services, communicate with co-workers being involved in international projects, participate in educational and training programs arranged by foreign partners, solve a wide variety of work-related problems communicating on-line or by the phone.

Most technical students have quite incorrect ideas about what is involved in learning pronunciation - or in learning a language in general, for that matter. So, G. Kelly suggests that "teachers regard features of pronunciation as integral to language analysis and lesson planning... in order to give students the full picture, and hence a better chance of being able to communicate successfully" [15, p. 13].

Thus learners should be constantly supported and well-organized, have time and patience, focused on continuity and awareness [19, p. 17]. The teacher can take the opportunity to give learners general guidelines in how to figure out what has gone wrong if they are not understood [10, p. 41].

The authors [5] focus on the importance of getting pronunciation priorities and mention that an off-target pronunciation might sound comical, irritating or distracting to listeners. They suggest a cutting-edge model for extensive practicing English pronunciation (each sound is described in detail, practiced in words in stressed and unstressed syllables, then the words are given in phrases and sentences to explore how their sound can change) supported by a website.

Problems and Solutions. In the conditions of the market demand for IT and telecoms specialists able to perform in the international environment, a person who "consistently mispronounces a range of phonemes can be extremely difficult for a speaker from another language community to understand" [15]. Our teaching practice in the Institute of Telecommunication Systems shows that the primary task is to be able to identify what difficulties language learners might encounter taking into consideration each aspect of phonology. It is obvious that most students find it difficult to pronounce the sounds which do not exist or have no equivalent in their native language. We have found out that for students who are native Ukrainian speakers the most challenging sounds in terms of developing both productive and receptive skills are: to produce English consonants $[\theta],[ð],[r],[\eta]$; to recognize the articulatory difference between

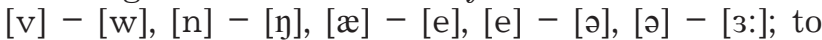
identify the difference in length of the short and

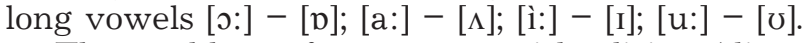

The problem often occurs with elision (disappearance of a sound), linking [r] (links the preceding vowel to a following one), contractions (two words are pronounced as one word or syllable), unusual sound combinations or clusters.

Another problem also occurs with the word stress, since the meaning of words can be understood through stress. Stressing the wrong syllable might make the word difficult to perceive and understand. There are words in English the meaning of which changes, if they are stressed on different syllable [6]. Some of them keep the general meaning, but change from noun to verb (e.g. PRO-duce/pro-DUCE, CON-vert/con-VERT, $R E$-cord/re-CORD, IN-crease/in-CREASE, RE-call/ re-CALL, RE-ject/re-JECT, CON-test/con-TEST). Others change their meaning, if they change from noun to verb or adjective (e.g. CON-duct/conDUCT, CON-tent/con-TENT, PRO-ject/pro-JECT, CON-verse/co-VERSE, AD-dress/ad-DRESS, EXploit/ex-PLOIT). Besides, mistakes in word stress are common when students use international words or specific terms (e.g. football, telephone, email, mobile, computer, telephony, telegraph, access, support, service, percent, etc.).

Still another aspect of phonology that causes trouble for technical students is sentence stress and intonation. Since meaning is conveyed by stress, it is necessary for them to identify stress in order to fit it all in. Intonation is considered to be the most significant aspect of pronunciation. It is used to convey the meaning, as well as to show the speaker's mood or attitude to what is happening. Using the wrong intonation leads to the problem of reception and understanding the meaning or function of an utterance.

As it is mentioned [10, p. 37] pronunciation is a skill, and practice is just as important as cognitive understanding, hence, the best way to resolve the above-mentioned problems is to focus on finding ways of integrating pronunciation into teaching and training, and including into lesson plans an appropriate set of relevant exercises, activities and drilling. 
There are two key approaches to pronunciation teaching: developing productive skills and receptive skills. While developing receptive skills students need to identify the difference between phonemes to learn how to produce them legibly.

Since the hours allotted to ESP in technical higher institutions are limited, we try to motivate students to gain phonological competence in both environments: in classes as well as independently.

As we have found out it is very important to help students to improve their pronunciation while learning new vocabulary related to their specialty. As J.P. Geyser states "there is very little point in students learning a new word, learning what it means and how to use it in a sentence, if no one understands them when they say it because their pronunciation is very poor" [11, p. 124]. Working on technical terminology it is necessary to practice 'syllable stress', 'unstress', 'schwa' (/ə/), 'weak form', 'rhythm' 'vowel' and 'consonant' [19, p. 23]

For learners who are expected to work in international environments it is very crucial to listen to and understand a wide range of accents in English, so we use audio and video materials to listen to recordings of speakers of different varieties of English.

It is worth paying much attention to the sounds (phonemes) that can change the meaning of words and lead to communication breakdowns.

Apart from mastering the vowels and consonants (segments), special attention is to be given to the correct use of weak forms and contractions that help learners to make their speech fluent and more authentic. It is also very important to make them familiar with assimilation (sounds that change under the influence of neighbouring sounds), elision (disappearing sounds) and liaison (linking of sounds across word boundaries) [5] the components which comprise phonological competence.

Our experience in ESP teaching to information and telecommunication students proves that learning correct pronunciation is essential at all stages of study. The lecturer's task is to decide on the approach to apply and adjust it to students' levels.

We would recommend some effective techniques of developing phonological competence in the in-class environment:

Observation and explanation of sound mechanics/ making involves explanation and demonstration how the mouth moves, the position of the tongue and force of making various sounds. We use this technique in individual work with a student who has pronunciation difficulty or with a group if most learners have the same problem. Choral drilling seems to be more appealing to students since it helps students to get rid of fear to speak in the class and feel more confident, hence, make progress.

As mentioned that those students who are afraid to sound funny and avoid repeating and miming various sound patterns in the in-class environment, often speak with a flat, boring or even rude and offensive intonation [11, p. 134] so drilling [5;11;15;18;19] must not be ignored in developing phonological competence. It provides a model of a word, phrase or structure for students to copy through repetition and can be incorporated into the grammar/vocabulary study by making students repeat those words that are the most problematic ones. Involving all the students to re- peat simultaneously it prevents them from feeling afraid or shy and can help to build confidence.

Types of drilling - open pair drilling (one student asks another responds) and substitution drilling (substituting items of vocabulary in a drilling structures) suggested by Kelly - are definitely helpful to employ in ESP practices. With junior students it is effective to practice chaining to build the sentence up gradually until it is completed. In case the sentence is long or contains difficult words or sounds it is divided into parts, modelled separately for the students to repeat. Drilling is a helpful tool in practicing word stress, sentence stress and intonation.

Tongue Twisters $[11 ; 15]$ are a useful type of activity in perfecting one's pronunciation skills. It might be employed for practicing difficult phonemes, unusual sound combinations or clusters, rhythm and intonation. Students listen to tongue twisters and repeat them preferably in the same manner as the speaker does. Trying to repeat better and better each time students become more competitive with themselves and by encouraging them it can give good results in a short amount of time.

Reading Activities. Reading aloud enables learners to explore the links between spelling and pronunciation [15; 19], and develop legible production of phonemes, word and sentence stress, and intonation.

Some teachers do not approve the idea of dedicating much time to reading in classes, others spent hours on reading explaining that in ESP it is crucial. We are sure that reading must not be neglected but rationally proportioned with other activities. 10-15 minute session of reading aloud in each class allows learners to get rid of the most phonological difficulties. While reading aloud they hear the mistakes they are making in intonation or sounds that are hard to master. It enables learners to recognize the difference between spoken language and printed structure. Aloud reading of dialogues helps them to practice stress and intonation and at the same time discover people's emotional states and the ways they express their attitudes towards other people or events.

There are various ways of mastering pronunciation in both environments: in-class and independently. Due to the fact that modern technical students prefer using smartphone-based technologies, the great advantage for them is to study and collaborate through smart technologies and online tools.

Dictionary work $[5 ; 9 ; 10 ; 11 ; 15 ; 18 ; 19]$. This method is crucial in learning pronunciation. It helps learners memorize words visually and correct themselves if they remembered them wrong. Students constantly use online dictionaries which are accessible and very easy and fast to use on their phones to look up the meaning of an unknown word but also listen to sound clips of how the word is pronounced.

An ESP teacher motivates students to learn the pronunciation of difficult specific terms by giving the instruction to check the word and incorporate this word into a sentence or a situation. This helps students to learn the pronunciation effectively not only when they are working by themselves but also in pairs or in small groups. It makes sense to practice active vocabulary of specialism-related terms. 
Jazz chants proposed by $[12 ; 19]$ are pattern drills based on a combination of repetition and learner response employed to practice English natural stress and intonation. It is a natural and interactive process to master pronunciation of phonemes, word and sentence structure, stress, rhythm and intonation.

For our students we use chants on small talk and grammar (Grammarchants Jazz Chants), related topics ("My computer crashed", "Nikola Tesla Song). The sources of chant material are available through the internet. This technique allows students to reduce anxiety, feel relaxed and more comfortable, helps teachers to make classes more enjoyable and motivated. They are helpful for learners to "build on their sense of rhythm to develop their awareness and to practise the rhythms of English" [19, p. 94].

Listening activities $[10 ; 15 ; 19]$ are aimed at developing receptive skills which are critical in building phonological competence. As it was mentioned above, they are needed for learners to be able to recognize, identify and exploit the sound structure of the language. As we have noticed IT and telecoms students are eager to use audio books or watch movies in mastering English pronunciation and found this way of learning to be both instructive and entertaining. Most of all they prefer series based on hacking and computer or smartphones technologies. A lot of students are subscribed to different English Websites, Podcasts and Youtube Channels according to their interests and professional needs. They listen to vloggers (someone who makes short films to record thoughts, ideas or opinions on a subject and posts them on the internet [4]) from different English speaking countries that makes it possible to keep abreast of all novelties and words and phrases which are currently in the trend. It makes them feel interested, motivated and able to masters pronunciation and communicative skills with great pleasure.

Conclusion. Employment market changes and demand for high performers make educators find the answers to how to teach ESP students to meet their needs to be competitive. Needs analysis can serve as an effective tool to explore the language competences to be developed. Since foreign language communicative competence in information and telecommunication fields are as vital as the relevant technical qualification, a special attention is to be given to developing phonological competence as one of its component.

Nowadays students can choose any efficient and expedient method of mastering English pronunciation depending on their needs and opportunities. The most effective techniques to solve the abovementioned problem are described relying upon the ESP practices with students who major in electronic and computer engineering. It is obvious that ESP students become more aware and confident, find purpose and motivation in their learning when applied approaches meet their professional needs and interests.

Prospects for further research are to incorporate smart technologies in ESP teaching.

\section{References:}

1. Basturkmen, H. (2006). Ideas and Options in English for Specific Purposes, New Jersey: L. Erbaum Associates.

2. Borysko, N. F. (2011). Metodyka formuvannya inshomovnoyi fonetychnoyi kompetenciyi [Methodology of Developing Foreign Language Phonological Competence]. Inozemni movy, 3, (3-14). Available at: http://nbuv.gov.ua/UJRN/im_2011_3_2.

3. Broda, M. V. (2011). Dydaktychni umovy zabezpechennya innovacijnyx procesiv u vyvchenni fonetyky anglijskoyi movy u vyshhyx navchalnyx zakladax [Didactic Terms of Providing Innovative Processes in English Phonetics Learning at Higher Educational Institutions]. Vykladannya mov u vyshh. navch. zakl. osvity na suchas. etapi. Mizhpredmet. zvyazky, 18, (46-55).

4. Cambridge Dictionary. Cambridge University Press [Online dictionary]. Retrieved 29.12.2018 from: https://dictionary.cambridge.org/dictionary/english/vlogger.

5. Carley, P., Mees, Inger M., Collins, B. (2018). English Phonetics and Pronunciation Practice. New York. Available at: https://books.google.com.ua/books?id=n6QzDwAAQBAJ\&pg=PT509\&lpg=PT509\&dq=enjoy+practicing+phon etics\&source=bl\&ots $=$ tnvHBPRyUe\&sig $=$ LhjjGtIa7gsDiqBTlw6uhQiW4yg\&hl=ru\&sa $=$ X\&ved $=2 a h U K E w j 0 \mathrm{nb}$ 6TmbLfAhXFjCwKHR1xB6EQ6AEwCXoECAMQAQ\#v=onepage\&q=enjoy\%20practicing\%20phonetics\&f=false

6. Change the stress, change the meaning: 35 words that change the meaning. Available on line at: https://www.engvid.com/english-resource/35-words-stress-changes-meaning/.

7. Common European Framework of Reference for Languages: Learning, Teaching, Assessment Council of Europe. (2001). Council for Cultural Co-operation. Education Committee. Modern Languages Devision. Cambridge University Press.

8. Dudley-Evans, Tony \& Jo St John, Maggie. (2003). Developments in ESP: A multi-disciplinary approach. Cambridge University Press.

9. Fraser, H. (2000). Coordinating improvements in pronunciation teaching for adult learners of English as a second language. Department of Education, Training and Youth Affairs (Australian National Training Authority Adult Literacy National Project): Canberrra.

10. Fraser, H. (2001). Teaching pronunciation: A handbook for teachers and trainers. Department of Education Training and Youth Affairs (DETYA). Available at: http://www.dest.gov.au/ty/litnet/docs/Teaching_Pronunciation.pdf.

11. Geyser, Jason Peter. (2006). English to the World: Teaching Methodology Made Easy: A Practical Overview. August Publishing.

12. Graham, C. (2001). Jazz chants: Old and new. New York: Oxford University Press.

13. Graves, K. (2006). Teachers as Course Developers. Cambridge University Press.

14. Hutchinson, T. \& Waters, A. (2006). English for specific purposes: a learning-centred approach. Glasgow: Cambridge University Press.

15. Kelly, G. (2000). How to Teach Pronunciation. Pearson Education Limited: Harlow, UK.

16. Nazarenko, O. (2016). "Effective Approaches to Teaching ESP to Telecommunications Specialists", Journal ["Scientific Letters of Academic Society of Michal Baludansky"], ISSN 1338-9432, (Kosice, Slovakia, January 2016: 4, 1. (122-125 pp.). 
17. Tsvietaieva, O., Znanetska, O. (2018). Fonetychni skladnosti anhliiskoi movy u studentiv nemovnykh spetsialnostei [Phonetic difficulties of the English language for students of non-linguistic specialties]. Liudynoznavchi studii. Seriia «Pedahohika» - Human Studies. Series of «Pedagogy», 6/38, 340-351. doi: 10.24919/2313-2094.6/38.121463 [in Ukrainian].

18. Yates, L. (2002). What is pronunciation? - Adult Migrant English Program (AMEP). Research Centre Fact Sheets, Sydney, National Centre for English Language Teaching and Research, Macquarie University, Retrieved 20.12.2018 from: http://www.ameprc.mq.edu.au/docs/fact_sheets/01Pronunciation.pdf.

19. Yates, L., Zielinski B. (2009). Give it a go: Teaching Pronunciation to Adults, Sidney. National Centre for English Language Teaching and Research, Macquarie University, Commonwealth of Australia. Retrieved 25.12.2018 from: http://www.ameprc.mq.edu.au/_data/assets/pdf_file/0006/276135/interactive_sm.pdf.

Назаренко O.I.

Національний технічний університет України

«Київський політехнічний інститут імені Ігоря Сікорського»

\title{
ПРОБЛЕМИ ФОРМУВАННЯ ФОНОЛОГІЧНОЇ КОМПЕТЕНТНОСТІ У СТУДЕНТІВ ТЕХНІЧНИХ СПЕЦІАЛЬНОСТЕЙ В НАВЧАННІ АНГЛІЙСЬКОЇ МОВИ ПРОФЕСІЙНОГО СПРЯМУВАННЯ ТА ШІЛЯХИ ЇХ ВИРІШЕННЯ
}

\author{
Анотація \\ Зміст статті зосереджено на важливості формування фонологічної компетентності як невід’ємного \\ складника іншомовної комунікативної компетентності. Описано проблеми навчання вимові студентів \\ технічних спеціальностей у вивченні англійської мови. Аналіз потреб студентів представлено як ефек- \\ тивний інструмент дослідження комунікативної компетентності, яку необхідно розвивати у навчан- \\ ні англійської мови професійного спрямування, щоб задовольнити запит ринку праці на спеціалістів \\ IT та телекомунікацій. Представлені найдоцільніші прийоми, щоб мотивувати студентів впевнено \\ й ефективно спілкуватися в іхньому академічному та професійному середовищі. \\ Ключові слова: англійська мова профресійного спрямування, аналіз потреб, іншомовна комунікативна \\ компетентність, фонологічна компетентність. \\ Назаренко О.И. \\ Национальный технический университет Украины \\ «Киевский политехнический институт имени Игоря Сикорского»

\section{ПРОБЛЕМЫ ФОРМИРОВАНИЯ ФОНОЛОГИЧЕСКОЙ КОМПЕТЕНТНОСТИ У СТУДЕНТОВ ТЕХНИЧЕСКИХ СПЕЦИАЛЬНОСТЕЙ В ИЗУЧЕНИИ АНГЛИЙСКОГО ЯЗЫКА ДЛЯ ПРОФЕССИОНАЛЬНЫХ ЦЕЛЕЙ И ПУТИ ИХ РЕШЕНИЯ}

\begin{abstract}
Аннотация
Содержание статьи сконцентрировано на важности развития фонологической компетентности как неотъемлемого компонента иноязычной коммуникативной компетентности. Анализ потребностей студентов представлен как эффективный инструмент исследования коммуникативной компетентности, которую необходимо формировать в обучении английского языка для профессиональных целей, чтобы удовлетворить требования рынка труда для специалистов IT и телекоммуникаций. Описаны наиболее целесообразные приемы, чтобы мотивировать студентов уверено и эфрфективно общаться в их академической и профрессиональной среде.

Ключевые слова: английский язык для профрессиональных целей, анализ потребностей, иноязычная коммуникативная компетентность, фонологическая компетентность.
\end{abstract}

